\title{
PENERAPAN MODEL PEMBELAJARAN QUANTUM TEACHING UNTUK MENINGKATKAN KEMAMPUAN PEMECAHAN MASALAH MATEMATIS SISWA
}

\author{
Asep Sujana1, Upi Asiah²
}

\begin{abstract}
This study aims to determine whether the learning model of Quantum Teaching can improve the ability of solving mathematical problems of students in grade VIII SMPN 1 Cinangka Serang District Academic Year 2017/2018. This study used quasi experimental research, the research design used was pretest-posttest control group design and sampling using cluster random sampling with class VIII E as many as 32 students as experimental class and class VIII D as many as 32 students as control class. The result of posttest hypothesis test shows that learning with Quantum Teaching model is better than conventional learning with tcount $=3.087$ and ttable $=1,999$ so $\mathrm{HO}$ is rejected. The result of the gain test shows thitung = 2,922 so HO is rejected then it shows that the learning model of Quantum Teaching can improve the mathematical problem solving ability of the students of grade VIII SMPN 1 Cinangka Serang regency for academic year 2017/2018.
\end{abstract}

Keywords : Quantum Teaching, Solving Mathematical Problems Ability

ABSTRAK: Penelitian ini bertujuan untuk mengetahui apakah model pembelajaran Quantum Teaching dapat meningkatkan kemampuan pemecahan masalah matematis siswa kelas VIII SMPN 1 Cinangka Kabupaten Serang Tahun Ajaran 2017/2018. Penelitian ini menggunakan penelitian kuasi eksperimen, desain penelitian yang digunakan adalah pretest-posttest control group design dan pengambilan sampel menggunakan cluster random sampling dengan kelas VIII E sebanyak 32 siswa sebagai kelas eksperimen dan kelas VIII D sebanyak 32 siswa sebagai kelas kontrol. Hasil uji hipotesis posttest menunjukan bahwa pembelajaran dengan model Quantum Teaching lebih baik dari pembelajaran konvensional dengan nilai thitung $=3,087$ dan tabel $=1,999$ sehingga $\mathrm{H}_{0}$ ditolak. Hasil uji gain menunjukan nilai thitung $=$ 2,922 sehingga $\mathrm{H}_{0}$ ditolak maka hal ini menunjukan bahwa model pembelajaran Quantum Teaching dapat meningkatkan kemampuan pemecahan masalah matematis siswa kelas VIII SMPN 1 Cinangka kabupaten Serang tahun ajaran 2017/2018.

Kata Kunci : Quantum Teaching, Kemampuan Pemecahan Masalah Matematis

\section{PENDAHULUAN}

Pendidikan merupakan kebutuhan yang sangat penting dan berlangsung sepanjang masa. Pendidikan pada dasarnya dapat membantu manusia dalam mengembangkan dirinya, sehingga mampu menghadapi perubahan yang terjadi dalam kehidupannya. Pendidikan yang baik akan menghasilkan sumber daya manusia yang berkualitas baik bagi diri sendiri, bangsa, dan negara sehingga mampu bersaing dan berkompetisi dengan negara lain. Dengan demikian, pendidikan harus betul-betul diarahkan untuk menghasilkan manusia yang berkualitas dan mampu bersaing disamping memiliki budi pekerti luhur dan moral yang baik, dalam upaya meningkatkan kualitas sumber daya manusia tidak terlepas dari pembelajaran yang berkualitas. Pembelajaran merupakan komunikasi dua

\footnotetext{
${ }^{1}$ Dosen Pendidikan Matematika, Universitas Mathla'ul Anwar, Email: ikasep123@gmail.com

${ }^{2}$ Mahasiswa Pendidikan Matematika, Universitas Mathla'ul Anwar, Email: upiasiah@gmail.com
} 


\section{Penerapan Model Pembelajaran Quantum Teaching Untuk Meningkatkan Kemampuan Pemecahan Masalah Matematis Siswa}

\section{ASEP SUJANA, UPI ASIAH}

arah, mengajar dilakukan oleh pihak guru sebagai pendidik, sedangkan belajar dilakukan oleh peserta didik. Surya (2003: 13) mengemukakan bahwa proses pembelajaran ialah proses individu mengubah perilaku dalam upaya memenuhi kebutuhannya. Dimyati (Susanto, 2012: 186) mengemukakan bahwa pembelajaran adalah kegiatan guru secara terprogram dalam desain instruksional, untuk membuat siswa belajar secara aktif, yang menekankan pada penyediaan sumber belajar. Pembelajaran berarti aktivasi guru dalam merancang bahan pengajaran agar proses pembelajaran dapat berlangsung secara aktif dan bermakna.

Salah satu bidang ilmu yang dipelajari oleh peserta didik adalah matematika. Matematika sebagai ilmu dasar memegang peranan yang sangat penting dalam pengembangan sains dan teknologi, karena matematika merupakan sarana berpikir untuk menumbuh kembangkan cara berpikir logis, sistematika, dan kritis. Aplikasi bidang matematika juga dapat diterapkan pada bidang lainnya sehingga tidak berlebihan jika kita katakan bahwa matematika adalah ilmu dasar. Namun disamping itu matematika merupakan salah satu bidang ilmu yang kerap ditakuti peserta didik. Hal tersebut harus dihilangkan karena sebagai ilmu dasar dan ilmu bantu bagi bidang ilmu lain, matematika memiliki peranan yang sangat penting. Susanto (2012: 183) mengemukakan bahwa matematika merupakan salah satu bidang studi yang ada pada semua jenjang pendidikan, mulai dari tingkat dasar hingga perguruan tinggi. Bahkan matematika diajarkan ditaman kanak-kanak secara informal.

Pembelajaran matematika adalah proses belajar mengajar yang dibangun oleh guru untuk meningkatkan kemampuan matematika siswa. pembelajaran matematika merupakan suatu proses belajar mengajar yang mengandung dua jenis kegiatan yang tidak terpisahkan. Kegiatan tersebut adalah belajar dan mengajar. Kedua aspek ini akan berkolaborasi secara terpadu menjadi suatu kegiatan pada saat terjadi interaksi antara siswa dengan guru, siswa dengan siswa, dan siswa dengan lingkungan saat pembelajaran berlangsung. Setiap orang yang menggeluti bidang apapun membutuhkan matematika untuk berpikir matematis, bernalar, berlogika, berfikir kritis, berfikir kreatif, berkomunikasi dengan baik, memprediksi dan mengambil keputusan. Hal ini menjadi penyebab matematika dijadikan salah satu prasyarat kelulusan. Namun berdasarkan pengalaman di lapangan, siswa masih menganggap matematika sebagai pelajaran yang sulit, menakutkan, dan membosankan.

SMPN 1 Cinangka yang berada di kecamatan Cinangka merupakan salah satu sekolah yang masih menggunakan pembelajaran yang siswanya cenderung pasif, hal ini dibuktikan dari hasil pengamatan peneliti saat observasi pada tanggal 29-30 Maret 2016. Saat pembelajaran berlangsung siswa cenderung menerima apa saja yang disampaikan guru, guru masih menggunakan pembelajaran konvensional yang berpusat pada kegiatan menjelaskan materi, memberikan contoh dan kemudian memberikan latihan soal.

Selain itu, dari hasil UTS dan UAS pada kelas VIII semester ganjil belum mencapai KKM yaitu 75, rata-rata hasil UTS pada kelas VIIIA-VIIIG adalah 59,8 dan UAS 38,6. Guru matematika kelas VIII mengemukakan salah satu penyebab rendahnya hasil UTS dan UAS disebabkan oleh siswa yang masih kesulitan dalam memecahkan persoalan matematika dan menentukan unsur unsur soal seperti apa yang diketahui dan ditanyakan. 


\section{Penerapan Model Pembelajaran Quantum Teaching Untuk Meningkatkan Kemampuan Pemecahan Masalah Matematis Siswa}

\section{ASEP SUJANA, UPI ASIAH}

Russefendi (Susanto, 2012: 14) menyatakan bahwa faktor-faktor yang memengaruhi hasil belajar diantaranya kecerdasan, kesiapan anak, bakat anak, kemauan belajar, minat anak, model penyajian materi, pribadi dan sikap guru, suasana belajar, kompetensi guru, dan kondisi masyarakat.

Pada saat observasi peneliti diberikan kesempatan untuk memasuki salah satu kelas VIII yaitu kelas VIII F, peneliti memberikan beberapa pertanyaan tentang matematika dan pembelajaran matematika seperti apa yang mereka inginkan, hampir seluruh siswa menjawab pembelajaran yang menyenangkan dan ceria. Berdasarkan fenomena tersebut maka harus di terapkan suatu model pembelajaran yang menyenangkan yang akan berpengaruh pada kemampuan pemecahan masalah siswa. Salah satu bentuk pembelajaran alternatif agar pembelajaran matematika lebih bermakna dan menyenangkan adalah melalui model Quantum Teaching.

Quantum Teaching merupakan proses pembelajaran dengan menyediakan latar belakang dan strategi untuk meningkatkan proses belajar mengajar menjadi menyenangkan. Quantum Teaching menciptakan lingkungan belajar yang efektif, yaitu dengan cara menggunakan unsur yang ada pada siswa dan lingkungan belajarnya melalui interaksi yang terjadi di dalam kelas. Pada dasarnya dalam pelaksanaannya Quantum teaching dikenal dengan singkatan TANDUR, yang merupakan kepanjangan dari : Tumbuhkan, Alami, Namai, Demonstrasikan, Ulangi dan Rayakan. Melaui tahap TANDUR ini siswa akan ditumbuhkan motivasi belajar nya dan mengalami secara langsung apa yang mereka pelajari jadi siswa bisa tahu masalah apa yang sedang mereka hadapi dan bagaimana cara memecahkan masalah tersebut, oleh karena itu quantum teaching diharapkan dapat meningkatkan kemampuan pemecahan masalah siswa.

Pemecahan masalah merupakan bagian dari kurikulum matematika yang sangat penting karena dalam proses pembelajaran maupun penyelesaiannya, siswa dimungkinkan memproleh pengalaman menggunakan pengetahuan serta keterampilan yang sudah dimiliki untuk diterapkan pada pemecahan masalah yang bersifat tidak rutin. Gagne (Wena, 2008: 52) bahwa pemecahan masalah dipandang sebagai suatu proses untuk menemukan kombinasi dari sejumlah aturan yang dapat diterapkan dalam upaya mengatasi situasi yang baru. Pemecahan masalah tidak sekedar sebagai bentuk kemampuan menerapkan aturan-aturan yang telah dikuasai melalui kegiatan-kegiatan belajar terdahulu, melainkan lebih dari itu, merupakan proses untuk mendapatkan seperangkat aturan pada tingkat yang lebih tinggi. apabila seseorang telah mendapatkan suatu kombinasi perangkat aturan yang terbukti dapat dioperasikan sesuai dengan situasi yang sedang dihadapi maka ia tidak saja dapat memecahkan suatu masalah, melaikan juga telah berhasil menemukan sesuatu yang memungkinkan seseorang dapat meningkatkan kemandirian dalam berpikir.

Menurut Djamarah (Susanto, 2012: 197) bahwa pemecahan masalah merupakan suatu metode yang merupakan suatu metode berfikir, sebab dalam pemecahan masalah dapat digunakan metode-metode lainnya yang dimulai dengan pencarian data sampai kepada penarikan kesimpulan. Polya (Susanto, 2012: 197) menyebutkan ada empat langkah dalam pemecahan masalah yaitu:

1. Memahami masalah, langkah ini meliputi :

1.) Apa yang diketahui, keterangan apa yang diberikan, atau bagaimana keterangan soal. 


\section{Penerapan Model Pembelajaran Quantum Teaching Untuk Meningkatkan Kemampuan Pemecahan Masalah Matematis Siswa}

\section{ASEP SUJANA, UPI ASIAH}

2.) Apakah keterangan yang diberikan cukup untuk mencari apa yang ditanyakan.

3.) Apakah keterangan tersebut tidak cukup, atau keterangan itu berlebihan.

4.) Buatlah gambar atau notasi yang sesuai.

2. Merencanakan penyelesaian, langkah ini meliputi :

1) Pernahkah anda menemukan soal seperti ini sebelumnya, pernahkah ada soal yang serupa dalam bentuk lain.

2) Rumus mana yang dapat digunakan dalam masalah ini.

3) Perhatikan apa yang ditanyakan.

4) Dapatkah hasil dan metode yang lalu digunakan disini.

3. Melalui perhitungan, langkah ini menekankan pada pelaksanaan rencana penyelesaian yang meliputi:

1) Memeriksa setiap langkah apakah sudah benar atau belum

2) Bagaimana membuktikan bahwa langkah yang dipilih sudah benar

3) Melaksanakan perhitungan sesuai dengan rencana yang dibuat.

4. Memeriksa kembali proses dan hasil, langkah ini menekankan pada bagaimana cara kebenaran jawaban yang diperoleh, yang terdiri dari;

1) Dapatkah diperiksa kebenaran jawaban

2) Dapatkah jawaban itu dicari dengan cara lain

3) Dapatkah jawaban atau cara tersebut digunakan untuk soal-soal lain.

Adapun dalam penelitian ini, yang menjadi aspek kemampuan pemecahan masalah matematis adalah:

1. Memahami masalah yang meliputi kemampuan mengidentifikasi unsur-unsur yang diketahui dan ditanyakan.

2. Membuat rencana pemecahan masalah yang meliputi memilih strategi dan menyusun model matematika.

3. Melaksanakan rencana pemecahan masalah yang meliputi menerapkan strategi.

4. Menafsirkan solusi yang diperoleh meliputi memeriksa kembali jawaban yang sudah diperoleh.

Deporter (2010: 31) menyatakan bahwa quantum teaching menunjukan kepada anda menjadi guru yang baik. Quantum teaching cara-cara yang baru yang memudahkan proses belajar lewat pemanduan unsur seni dan pencapaianpencapaian yang terarah, apapun mata pelajaran yang anda ajarkan, dengan menggunakan model quantum teaching anda akan dapat menggabungkan keistimewaan-keistimewaan belajar menuju bentuk perencanaan pelajaran yang akan melejitkan prestasi siswa. Quantum teaching menciptakan lingkungan belajar yang efektif, yaitu dengan cara menggunakan unsur yang ada pada siswa dan lingkungan belajarnya melalui interaksi yang terjadi di dalam kelas.

Menurut Deporter (2010: 34), bahwa asas utama quantum teaching adalah bawalah dunia mereka kedunia kita dan antarkan dunia kita ke dunia mereka. Dari asas utama ini, dapat disimpulkan bahwa langkah awal yang harus dilakukan dalam pengajaran yaitu mencoba memasuki dunia yang dialami oleh peserta didik. Cara yang dilakukan seorang pendidik meliputi: untuk apa mengajarkan dengan sebuah peristiwa, pikiran atau perasaan yang diperoleh dari kehidupan rumah, sosial, atletik, musik, seni, rekreasi atau akademis mereka. Setelah kaitan itu terbentuk, maka dapat membawa mereka kedalam dunia kita dan memberi mereka pemahaman mengenai isi dunia itu. "Dunia kita" disinilah kosakata, rumus, dan lainlain dibeberkan dan dipeluas mencakup tidak hanya para siswa, tetapi juga guru. 


\section{Penerapan Model Pembelajaran Quantum Teaching Untuk Meningkatkan Kemampuan Pemecahan Masalah Matematis Siswa}

\section{ASEP SUJANA, UPI ASIAH}

Akhirnya dengan pengertian yang lebih luas dan penguasaan lebih mendalam, siswa dapat membawa apa yang mereka pelajari kedalam dunia mereka dan menerapkannya pada situasi baru. Prinsip quantum teaching yaitu:

1. Segalanya berbicara, artinya segalanya dari lingkungan kelas hingga bahasa tubuh guru, dari kertas yang dibagikan hingga rancangan pembelajaran, semuanya mengirimkan pesan tentang belajar.

2. Segalanya bertujuan, Semuanya yang terjadi dalam proses belajar mengajar mempunyai tujuan.

3. Pengalaman sebelum pemberian nama, berarti sebelum mendefinisikan, membedakan, siswa terlebih dahulu telah memiliki atau telah diberikan pengalaman informasi yang terkait dengan upaya pemberian nama.

4. Akui setiap usaha, berarti apapun usaha yang telah dilakukan siswa haruslah mendapat pengakuan dari guru maupun siswa lainnya.

Jika layak dipelajari, maka layak pula dirayakan, setiap usaha belajar yang dilakukan layak untuk dirayakan untuk memberi umpan balik dan meningkatkan asosiasi emosi positif dengan belajar. Agar proses pembelajarn dengan model quantum teaching ini dapat benar-benar sedinamis mungkin. Tahap-tahapan yang sering dikenal sebagai kerangka rancangan quantum teaching TANDUR yaitu:

1. Tumbuhkan, Tumbuhkan mengandung makna bahwa pada awal kegiatan pembelajaran pengajar harus bisa menumbuhkan motivasi dan semangat belajar siswa. Dan memberi tahu siswa bahwa merekalah yang bertanggung jawab atas pendidikan mereka sendiri, sehingga mereka tahu apa manfaat dari apa yang sedang mereka pelajari bagi diri mereka biasannya dikenal dengan AMBAK (Apa Manfaatnya Bagiku).

2. Alami, Alami mengandung makna bahwa proses pembelajaran akan lebih bermakna jika siswa mengalami secara langsung atau nyata.

3. Namai, Namai mengandung makna bahwa penamaan adalah saatnya untuk mengajarkan konsep, keterampilan berpikir dan strategi belajar. Penamaan mampu memuaskan hasrat alami otak untuk memberi identitas, mengurutkan, dan mendefinisikan.

4. Demonstrasi, Demonstrasikan mengandung makna bahwa memberi peluang pada siswa untuk menerapkan pengetahuan mereka ke dalam pembelajaran lain atau ke dalam kehidupan mereka.

5. Ulangi, Ulangi mengandung makna bahwa proses pengulangan dalam kegiatan pembelajaran dapat memperkuat koneksi saraf dan menumbuhkan rasa yakin terhadap kemampuan siswa.

6. Rayakan, Rayakan mengandung makna pemberian penghormatan kepada siswa atas usaha, ketekunan, dan kesuksesannya.

\section{METODE PENELITIAN}

Penelitian ini menggunakan metode kuasi eksperimen. penelitian eksperimen yaitu penelitian yang ditujukan untuk menjelaskan suatu masalah yang bersifat teoritik dan kasuistik, baik secara deskriptif maupun naratif berdasarkan hasil pengujian dan tes untuk menemukan hipotesis tertentu. Desain penelitian yang digunakan adalah pretest-posttest control Group design.

$$
\begin{array}{lll}
0 & X & 0 \\
0 & & 0
\end{array}
$$




\title{
Penerapan Model Pembelajaran Quantum Teaching Untuk Meningkatkan Kemampuan Pemecahan Masalah Matematis Siswa
}

\author{
ASEP SUJANA, UPI ASIAH
}

\begin{abstract}
Populasi dalam penelitian ini adalah seluruh kelas VIII SMPN 1 Cinangka dengan sampel penelitian yaitu kelas VIII D sebagai kelas kontrol dan VIII E sebagai kelas eksperimen. Pengambilan sampel menggunakan cluster random slamping . Instrumen pada penelitian berupa test uraian sebanyak 6 butir, dengan materi aljabar, dimana setiap butir soal memuat 4 indikator kemampuan pemecahan masalah matematis. Penelitian yang dilakukan ini menggunakan dua teknik dalam pengumpulan data, yaitu dokumentasi dan test. Instrumen dalam penelitian ini berupa lembar tes, lembar tes yang diberikan terdiri dari soal test awal dan soal test akhir. Soal tersebut terlebih dahulu dihitung nilai validitas, reliabilitas, daya pembeda dan indeks kesukaran. Berdasarkan hasil analisis data pretes, postes, dan gain ternyata data berdistribusi normal dan memiliki varians homogen dan statistik yang digunakan dalam menganalisis data menggunakan statistik parametrik dengan uji-t.
\end{abstract}

\section{HASIL DAN PEMBAHASAN}

Penelitian ini dilaksanakan di SMPN 1 Cinangka tahun pelajaran 2017/2018. Model pelajaran yang digunakan yaitu quantum teaching yang diberikan pada kelas eksperimen dan pembelajaran konvensional yang diberikan pada kelas kontrol. Kelas eksperimen pada penelitian ini yaitu kelas VIII E dengan jumlah siswa 32, sedangkan kelas kontrol yaitu kelas VIII D dengan jumlah siswa 32. Pokok bahasan yang diberikan yaitu aljabar dengan pertemuan sebanyak 8 kali, 6 pertemuan untuk pembelajaran dan 2 pertemuan untuk pretest dan posttest.

Diawal pertemuan peserta didik diberikan pretest untuk mengetahui kemampuan awal sebelum diberikan perlakuan, setelah diberikan pretest peserta didik malakukan kegiatan belajar mengajar dengan perlakuan yang berbeda, dan ketika pembelajaran selesai selama 6 pertemuan, peserta didik diberikan posstest. Pretest dan posstest diberikan kepada peserta didik yang ada di kelas sampel tersebut dengan soal yang sama. Soal yang diberikan berupa soal uraian yang terdiri dari 5 butir soal yang sudah dilakukan uji coba. Setelah diketahui skor pretest dan posttest nya lalu ditentukan skor gain. Skor gain diperoleh dari skor kemampuan pemecahan masalah matematika siswa melalui skor pretest dan posttest yang dimaksudkan untuk mengetahui peningkatan kemampuan pemecahan masalah matematika siswa pada kelas eksperimen dan kelas kontrol.

Berdasarkan hasil perhitungan data pretes kelas eksperimen memiliki nilai terendah 4, tertinggi 21, mean 13,09, median 14,00, modus 19 dan simpangan baku 5,515, sedangkan data pretes kelas kontrol memiliki nilai terendah 2, nilai tertinggi 19, mean 12,44, median 12,00, modus 16 dan simpangan baku 4,628. Hasil data postes kelas eksperimen memiliki nilai terendah 18 , tertinggi 46 , mean 31,25, median 34,00, modus 38 dan simpangan baku 8,207, sedangkan kelas kontrol memiliki nilai terendah 15 , nilai tertinggi 50, mean 24,84, median 23,50 , modus 15 dan simpangan baku 8,394. Hasil data gain kelas eksperimen memiliki nilai terendah 0 , tertinggi 0,913 , mean 0,49 , median 0,49 , modus 0,66 dan simpangan baku 0,22, sedangkan kelas kontrol memiliki nilai terendah 0,03 , nilai tertinggi 1 , mean 0,32, median 0,31, modus 1 dan simpangan baku 0,23 .

Uji hipotesis data pretest digunakan untuk mengetahui apakah terdapat perbedaan kemampuan awal siswa kelas eksperimen dengan kelas kontrol. Karena data berdistribusi normal dan homogen maka uji hipotesis menggunakan uji-t. 


\section{Penerapan Model Pembelajaran Quantum Teaching Untuk Meningkatkan Kemampuan Pemecahan Masalah Matematis Siswa}

\section{ASEP SUJANA, UPI ASIAH}

Berdasarkan uji hipotesis data pretes pada taraf signifikansi $\alpha=0,05$ diperoleh data seperti pada Tabel 1 berikut.

Tabel 1

Hasil Uji-t Pretest

\begin{tabular}{|l|l|l|l|l|}
\hline$t_{\text {hitung }}$ & $t_{\text {tabel }}$ & Sig $(2-$ tailed $)$ & Signifikan & Keterangan \\
\hline 0,516 & 1,999 & 0,608 & $5 \%$ & Terima $\mathrm{H}_{0}$ \\
\hline
\end{tabular}

Berdasarkan Tabel 1 diperoleh nilai $\mathrm{t}_{\text {hitung }}<\mathrm{t}$ tabel yaitu 0,516 $<1,999$ dan nilai Sig. (2-tailed) > 0,05. Hal ini sesuai dengan kriteria pengujian, maka $H_{a}$ ditolak, sehingga $\mathrm{H}_{0}$ diterima yaitu tidak terdapat perbedaan kemampuan awal siswa antara kelas eksperimen dengan kelas kontrol.

Uji hipotesis pada data postes digunakan untuk mengetahui kemampuan pemecahan masalah matematika siswa yang memperoleh model pembelajaran quantum teaching dan siswa yang memperoleh pembelajaran konvensional. Karena data berdistribusi normal dan homogen maka uji hipotesis menggunakan uji-t. Berdasarkan uji hipotesis data postes pada taraf signifikansi $\alpha=0,05$ diperoleh data seperti pada Tabel 2 berikut.

Tabel 2

Hasil Uji-t Postes

\begin{tabular}{|l|l|l|l|l|}
\hline$t_{\text {hitung }}$ & $t_{\text {tabel }}$ & $\begin{array}{l}\text { Sig (2 - } \\
\text { tailed) }\end{array}$ & Signifikan & Keterangan \\
\hline 3,087 & 1,999 & 0,003 & $5 \%$ & Terima $\mathrm{H}_{1}$ \\
\hline
\end{tabular}

Berdasarkan Tabel 2 diperoleh nilai $t_{\text {hitung }}>t_{\text {tabel }}$ yaitu 3,087 $>1,999$ dan nilai Sig. (2-tailed) $>0,05$. Hal ini sesuai dengan kriteria pengujian, maka $H_{a}$ diterima, sehingga $\mathrm{H}_{0}$ ditolak yaitu kemampuan pemecahan masalah matematika siswa yang mendapatkan model pembelajaran quantum teaching lebih baik dari pada siswa yang mendapatkan pembelajaran konvensional.

Uji hipotesis gain digunakan untuk menguji apakah penerapan model pembelajaran Quantum Teaching dapat meningkatkan kemampuan pemecahan masalah matematis siswa. Karena data berdistribusi normal dan homogen maka uji hipotesis menggunakan uji-t. Berdasarkan uji hipotesis data gain pada taraf signifikansi $\alpha=0,05$ diperoleh data seperti pada Tabel 3 berikut.

Tabel 3

Hasil Uji-t Gain

\begin{tabular}{|l|l|l|l|l|}
\hline$t_{\text {hitung }}$ & $t_{\text {tabel }}$ & $\begin{array}{l}\text { Sig (2 - } \\
\text { tailed) }\end{array}$ & Signifikan & Keterangan \\
\hline 2,922 & 1,999 & 0,005 & $5 \%$ & Terima $\mathrm{H}_{1}$ \\
\hline
\end{tabular}




\section{Penerapan Model Pembelajaran Quantum Teaching Untuk Meningkatkan Kemampuan Pemecahan Masalah Matematis Siswa}

\section{ASEP SUJANA, UPI ASIAH}

Berdasarkan tabel 3 diperoleh nilai $t_{\text {hitung }}>t_{\text {tabel }}$ yaitu 3,087 $>1,999$ dan nilai Sig. (2-tailed) $>0,05$. Hal ini sesuai dengan kriteria pengujian, maka $H_{0}$ ditolak, sehingga $\mathrm{H}_{\mathrm{a}}$ diterima yaitu Penerapan model pembelajaran quantum teaching dapat meningkatkan kemampuan pemecahan masalah matematis siswa.

Penelitian ini bertujuan untuk meningkatkan kemampuan pemecahan masalah matematis siswa kelas VIII SMP Negeri 1 Cinangka dengan menggunakan model pembelajaran Quantum Teaching. Diawal pertemuan peserta didik diberikan pretest untuk mengetahui kemampuan awal sebelum diberikan perlakuan, berdasarkan hasil perhitungan dengan menggunakan SPSS Versi 16.0 diperoleh bahwa rata-rata kelas eksperimen lebih besar dari kelas kontrol namun perbedaannya masih sangat kecil yaitu 13,09 untuk kelas eksperimen dan 12,44 untuk kelas kontrol. Selain itu pada analisis data diperoleh bahwa data Pretest berdistribusi normal dan homogen, sehingga dalam pengujian hipotesis menggunakan uji-t . Setelah dilakukan uji hipotesis diperoleh nilai t hitung sebesar 0,516 dan $\mathrm{t}$ tabel sebesar 1,999 atau $\mathrm{t}$ hitung $<\mathrm{t}$ tabel maka $\mathrm{H}_{0}$ diterima yaitu tidak terdapat perbedaan kemampuan awal siswa kelas eksperimen dengan kelas kontrol.

Setelah diberikan pretest peserta didik malakukan kegiatan belajar mengajar dengan perlakuan yang berbeda, kelas eksperimen menggunakan model pembelajaran Quantum Teaching dan kelas kontrol menggunakan model pembelajaran konvensional kemudian setelah pembelajaran selesai selama 6 pertemuan, peserta didik diberikan posstest. Berdasarkan hasil perhitungan dengan menggunakan SPSS Versi 16.0 diperoleh bahwa rata-rata kelas eksperimen lebih besar dari kelas kontrol dan perbedaannya cukup besar yaitu 31,25 untuk kelas eksperimen dan 24,84 untuk kelas kontrol. Selain itu pada analisis data diperoleh bahwa data Pretest berdistribusi normal dan homogen, sehingga dalam pengujian hipotesis menggunakan uji-t. Setelah dilakukan uji hipotesis diperoleh nilai t hitung sebesar 3,087 dan $\mathrm{t}$ tabel 1,999 atau $\mathrm{t}$ hitung $>\mathrm{t}$ tabel maka $\mathrm{H}_{\mathrm{a}}$ diterima yaitu penerapan model pembelajaran Quantum Teaching lebih baik dari pembelajaran konvensional.

Setelah dilakukan Pretest dan Posttest maka dilakukan perhitungan gain untuk melihat peningkatan kemampuan pemecahan masalah matematis pada kelas eksperimen dan kelas kontrol. Berdasarkan nilai N-Gain yang diperoleh kelas eksperimen lebih tinggi dari kelas kontrol. hasil perhitungan didapatkan nilai $t$ hitung sebesar 2,922 dan $t$ tabel 1,999 atau thitung $>t$ tabel. Hal ini sesuai dengan kriteria pengujian, maka $H_{0}$ ditolak, sehingga $\mathrm{H}_{1}$ diterima yaitu Penerapan model pembelajaran Quantum Teaching dapat meningkatkan kemampuan pemecahan masalah matematis siswa. Maka dapat disimpulkan bahwa penerapan model pembelajaran Quantum Teaching dapat meningkatkan kemampuan pemecahan masalah matematis siswa kelas VIII SMP Negeri 1 Cinangka.

\section{KESIMPULAN}

Dari penelitian yang telah dilakukan di SMP Negeri 1 Cinangka diperoleh kesimpulan bahwa penerapan model pembelajaran Quantum Teaching dapat meningkatkan kemampuan pemecahan masalah matematis siswa SMP Negeri 1 Cinangka. Hal ini dapat dilihat dari hasil N-Gain nilai rata - rata Gain kelas eksperimen lebih besar dari kelas kontrol dan perbedaannya cukup besar, sehingga 


\section{Penerapan Model Pembelajaran Quantum Teaching Untuk Meningkatkan Kemampuan Pemecahan Masalah Matematis Siswa}

\section{ASEP SUJANA, UPI ASIAH}

dapat disimpulkan bahwa peningkatan kemampuan pemecahan masalah matematis kelas eksperimen lebih tinggi dari kelas kontrol. Terbukti pada hasil uji-t. Dengan menggunakan taraf signifikansi $\alpha=0,05$ dengan $d f=62$, hasil perhitungan didapatkan

nilai $t_{\text {hitung }}=2,922$ dan $t_{\text {tabel }}=1,999$ sehingga $t_{\text {hitung }}>t_{\text {tabel }}=2,922>1,999$ dan nilai Sig ( 2 - tailed) $0,005<0,05$. Hal ini sesuai dengan kriteria pengujian, maka $H_{0}$ ditolak, sehingga $\mathrm{H}_{1}$ diterima yaitu Penerapan model pembelajaran Quantum Teaching dapat meningkatkan kemampuan pemecahan masalah matematis siswa.

Guru matematika hendaknya selalu melakukan perbaikan dan peningkatan kualitas pembelajaran dengan menggunakan model pembelajaran yang lebih variatif. Proses pembelajaran matematika hendaknya dapat disampaikan secara menyenangkan agar peserta didik tidak merasa bosan. Guru disarankan menggunakan model pembelajaran Quantum Teaching pada pembelajaran matematika. Calon guru diharapkan dapat mengembangkan model pembelajaran Quantum Teaching dan dapat menerapkannya baik pada proses pengalaman pelatihan lapangan atau pembelajaran lainnya. Bagi peserta didik hendaknya selalu memperhatikan pelajaran yang disampaikan oleh guru dengan seksama dan meningkatkan motivasi belajarnya, agar hasil belajar yang dicapai menjadi lebih baik.

\section{DAFTAR PUSTAKA}

Deporter, B. et al. (2010). Quantum Teaching. Bandung: Kaifa.

Kurdiatna, S. et. al. (2016). Pedoman Penulisan Skripsi FKIP 2016. Pandeglang: FKIP UNMA Banten.

Mawaddah, S \& Anisah, H. (2015). Kemampuan Pemecahan Masalah Matematis Siswa Pada Pembelajaran Matematika Dengan Menggunakan Model Pembelajaran Generatif (Generative Learning) Di Smp . Edu-Mat Jurnal Pendidikan Matematika. [0nline], Vol 3 (2), 9. Tersedia: http://www.google.Com//Ppjp.Unlam.Ac.Id/Fjourna/Findex.Php/Edumat. [ 28 Maret 2017].

Sugiyono. ( 2015) . Metode Penelitian Pendidikan. Bandung: Alfabeta.

Surya, M. (2003). Psikologi Pembelajaran dan Pengajaran. Bandung: Pustaka Bani Quraisy

Susanto,A. (2012). Teori Belajar \& Pembelajaran di Sekolah Dasar. Jakarta: Kencana.

Wena, M. (2008). Strategi Pembelajaran Inovatif Kontemporer. Malang : Bumi Aksara. 